\title{
Biotechnology's first casualty - so far
}

DNA Science

left out

\section{on a limb}

\section{Washington}

E.F. Hutton, one of Wall Street's leading investment houses, is having second thoughts about its involvement in recombinant DNA research. Earlier this month the company backed out of a deal it had set up which would have used money from over 40 institutional investors to support academic research in both US and foreign laboratories. Now it is talking of an alternative, less ambitious scheme exploiting recent changes in tax legislation to sell genetic engineering research as an attractive tax shelter.

The initial plan, first announced in February of this year, was to channel investment funds to scientists through a company set up by Hutton called DNA Science. The centrepiece of this scheme was an agreement with the Weizmann Institute of Science in Israel for collaboration on research projects. Weizmann would have provided the molecular biologists and DNA Science the chemistry through Nobel laureate Dr Christian B. Anfinsen, appointed chief scientist of an Israeli subsidiary called Taglit.

According to Hutton, the deal fell apart when the investment company began to have doubts about the legal propriety of mixing "passive" and "active" investors, some merely seeking a financial return, others demanding a greater involvement. The potential conflict between these goals surfaced when one proposed investor, Johnson and Johnson, began negotiating for exclusive marketing rights to any products which resulted from DNA Science-financed research.

Failure to reach agreement before a target date stipulated in the publiclydistributed prospectus, by which $\$ 40$ million was to have been raised, meant that Hutton was required to return the money it had already collected from outside investors. But the debate over the appropriate form of involvement by investors also reflects growing concerns that the potential commercial benefits of genetic engineering may have been oversold.

In addition to dropping the Weizmann deal, which would have focused largely on interferon, other proposals now being reassessed include an arrangement with the Battelle Memorial Institute in Columbus, Ohio, for research into projects such as the use of microorganisms to degrade toxic wastes, and collaboration with Dr John Baxter of the University of California in San Francisco.

Dr Harsanyi, vice-president of DNA Science, says the company will now concentrate on putting together individual projects or "packages of projects" for separate funding by groups of investors, rather than trying to raise the initial capital in one lump. This means shifting the focus from long-range research to projects with more clearly-defined commercial goals.

Exploiting the tax haven incentives offered by research and development financing that were recently increased by the federal government will exclude some of the original investors, such as pension funds, which already enjoy significant tax concessions.

Ironically Hutton was one of the first major financial houses to promote the long-range commercial potential of recombinant DNA research. Nelson $M$. Schneider, a pharmaceutical analyst with the company who is credited as the principal architect of DNA Science and is now one of its vice-presidents, reported to a congressional committee in June that, if present trends continue, by 1985 private companies could be putting as much into biomedical research as are the National Institutes of Health (NIH).

Under the scheme unveiled in February, which had been suggested as a model for university/industry collaboration in supporting recombinant DNA research,

\section{CERN declares peace with the locals}

The 26-km circumference large electronpositron ring (LEP) proposed for construction at CERN near Geneva seems to be steering itself successfully among the several political shoals that surround the project. The lastest development is that CERN and the most active environmental opposition group, Agena, have issued a mollifying joint statement.

Agena, which includes a local mayor among its six members, was successful in halting work on a reconnaissance gallery by means of a legal technicality. It has also been active in canvassing support against LEP within the Jura region of France, so any degree of rapprochement between Agena and CERN is significant.

In the statement, Agena says it is concerned about LEP polluting water and the air, and about LEP's possible effect of reducing employment at CERN (to help pay for the project). Agena asks that CERN should adopt a "different approach" and give local people time to express their opinions on the project.

For its part, CERN promises to consult all relevant associations and trade unions in "an atmosphere of cooperation"'; says that it "understands" Agena's fears; that anyone is free to speak to CERN and its director-general, Professor Herwig Schopper, and that no work will be done
DNA Science would have set up a number of small "daughter companies" near university campuses in which university staff could apply themselves to commercially-oriented research while maintaining their campus links.

This was to have been the arrangement with the Weizmann Institute under an agreement reached with the institute's commercial arm, the Yeda Research and Development Corporation. Dr Anfinsen said last week that he had resigned from his post as head of the laboratory of chemical biology at the NIH's National Institute of Arthritis, Metabolism and Digestive Diseases to take up the Israeli position with DNA Science. He said that he was waiting to see what happened at the Weizmann Institute, which might continue working in the same direction on its own, before deciding what to do next.

DNA Science of ficials are confident that much of their work in finding both investors and research projects needing support can be salvaged. Dr Harsanyi says that several university groups have approached Hutton, interested in exploiting their research, but reluctant to become involved in the commercial management of their results. DNA Science is offering to take on this management responsibility, which could include finding potential customers for products.

David Dickson

until an environmental impact statement is complete, and the French and Swiss authorities have been given time to react through the normal national channels providing planning permission.

This latter move is an important step for CERN - although Schopper proposed it at the June meeting of CERN Council, well before the joint statement with Agena. Legally, CERN is an international organization which officially needs to deal only with the foreign ministries of member and host states. But construction of LEP, reaching deep into French and Swiss territory far from the original CERN site, has occasioned new rules.

The principal step is the production of an environmental impact statement for the French Ministry of Research and Technology, the Ministry of Environment and the Ministry of External Relations in October. Then, under French law, a commission of inquiry will be set up which will assess local opinion and invite witnesses (including, presumably, Agena itself). The commission will report, and finally a decision will be taken either by the local préfet of the département or the Conseil d'Etat. This process could take until March 1982. Swiss law is less exacting, but the French process is likely to be longer.

Meanwhile, the French research ministry 
is taking steps to unblock the restraint on the LEP reconnaissance gallery, which depends on whether the gallery is a temporary or a permanent construction. If it is temporary, the law under which permission was originally granted is appropriate; if permanent - as Agena successfully argued - it is not. The ministry is attempting on the one hand to argue that the gallery is, after all, temporary and on the other to get approval through a different law. Robert Walgate

\section{Particle physics \\ Director resigns}

\section{Washington}

Dr George Vineyard, director of the Brookhaven National Laboratory on Long Island, New York State, announced last week that he is stepping down in order to return to full-time research. His resignation has been accepted "with regret" by the board of trustees of Associated Universities Inc., the consortium of nine universities which operates the Brookhaven Laboratory for the US Department of Energy. In a statement issued after the board's meeting last Monday, Dr Vineyard said that after nine years as director of Brookhaven, where he has been since 1954, "this appeared to be a good time to make the move".

His resignation has, however, inevitably been linked to growing speculation that the Reagan Administration is contemplating cutting funds for further development work on Brookhaven's planned $400 \times 400$ $\mathrm{GeV}$ intersecting storage accelerator (ISABELLE) which is facing delays and cost over-runs.

Uncertainty over the fate of ISABELLE has been growing ever since the laboratory encountered serious difficulties in developing the superconducting magnets, 1,100 of which will be required to complete the accelerator's two-mile circumference ring (Nature 286, 435; 1980).

Brookhaven now says that the problems with the magnets seem to have been solved with a new design, but the delays have inevitably resulted in cost over-runs. The bill for ISABELLE is now put at $\$ 500$ million, compared with an original estimate of $\$ 420$ million, and completion is now expected in 1988 rather than 1986.

Given the intense competition from the new proton-antiproton collider under construction at CERN in Geneva, which is now likely to beat ISABELLE to one of its principal goals, the discovery of weak vector bosons, those responsible for ISABELLE face a daunting task in maintaining political support for their machine.

Dr Vineyard denies that his resignation has anything to do with the problems with ISABELLE, pointing out that the accelerator has "turned the corner by overcoming technical difficulties with the superconducting magnets". He says that other research at the laboratory is in a healthy state, and that the new national synchroton light source is about to go into operation.

The Reagan Administration has, however, been making lukewarm noises about continued support. A meeting between the High Energy Physics Advisory Panel and the National Science Foundation next month is likely to discuss options. One is a scaled-down design, using superconducting magnets which have already been constructed at the Fermi National Laboratory but produce a slightly lower field that would mean a lower luminosity. Another is to scrap ISABELLE altogether. The Administration is awaiting the outcome of this meeting before deciding whether to go on as planned, or adopt one of these alternatives.

David Dickson

\section{Incoherent scatter radar Auroral visions}

A new high-power radar facility, designed to study the Earth's upper atmosphere and magnetosphere at auroral latitudes, was inaugurated by the King of Sweden on 26 August. The $£ 13$ million radar's operation will be supervized by the European Incoherent Scatter Association (EISCAT) whose headquarters are in Kiruna, Sweden. The director of the association is Tor Hagfors.

The member countries of EISCAT are West Germany, France, the United Kingdom (each contributing 25 per cent to the capital and running costs), Sweden, Norway (both 10 per cent) and Finland ( 5 per cent). Half the working time of the facility will be spent collecting data for common use. For the remainder, each country will have control of the facility for a time proportional to its financial contribution.

The radar was originally scheduled to start operation in 1978 but was delayed due to a faulty klystron - a vital transmitter component which turned out to be more difficult to develop than expected. The delay must have proved particularly frustrating to those itching to make their reputations with the new facility, but EISCAT's twenty or so staff have spent the time making astronomical observations with the receivers and developing computer software.

The facility consists of two radar systems, one operating at VHF $(224 \mathrm{MHz})$ which is expected to be ready by next year, and a tristatic UHF $(933 \mathrm{MHz})$ system with a transmitter/receiver at Tromso, Norway, and receivers at Kiruna and Sodankyla, Finland. The UHF system has already produced its first crop of data. The combined systems will be able to monitor the atmosphere from 50 to $3,000 \mathrm{~km}$.

The incoherent scatter technique, which EISCAT's radar utilizes, exploits the fact

\section{Deadline missed}

Legislation to bring Britain into line with the European Commission's directive on the notification of new chemicals will not now be enacted before the $18 \mathrm{Sep}$ tember deadline. The Health and Safety Executive acknowledged this week that too many problems still remain to be ironed out. And in any case, Parliament will not reconvene until October.

The executive is not, however, worried that the commission will take proceedings against the United Kingdom - the United Kingdom is not the only laggard. One source of confusion is that the European directive requires the compliance not merely of governments but of other corporate bodies, including commercial companies, which may find that after 18 September they are bound by the directive. The commission is planning to publish in the near future an inventory of all chemicals at present manufactured and sold in Europe. Companies will have nine months from the date of publication to tell the commission of substances not on the list. After that, new substances will have to be tested (toxicologically and otherwise) in accordance with the directive. Until then, however, the British and other European parliaments will have a breathing space in which to find time to comply.

Judy Redfearn

that radio waves can be scattered off individual electrons and off density variations caused by plasma waves in the ionosphere. This region of the atmosphere, which is ionized by solar and cosmic radiation, extends upwards from $50 \mathrm{~km}$ or so. The spectrum of backscattered radio pulses can be analysed to reveal a surprisingly large number of atmospheric parameters such as electron and ion densities, ion composition, electric fields, neutral and ionized wind velocities and temperatures.

Several incoherent scatter facilities have been constructed in the past, the most powerful being at Arecibo in Puerto Rico. Only one has operated at auroral latitudes, that at Chatanika in Alaska, which is itself to be moved to Greenland to allow more effective collaboration with EISCAT. The auroral zone is particularly important to those interested in solar-terrestrial relations because it is here that those relations are most manifest. For example, charged particles ejected from the Sun during solar disturbances can be trapped in the Earth's magnetosphere and may eventually spiral down the Earth's magnetic field lines to precipitate into the auroral upper atmosphere, causing heating and intense electric currents. EISCAT's sensitive radar should allow a detailed picture of such events to be developed, particularly when used in conjunction with other ground, rocket and satellite based experiments.
Philip Campbell 